\title{
Pretreatment with probiotics ameliorate gut health and necrotic enteritis in broiler chickens, a substitute to antibiotics
}

\author{
Danish Sharafat Rajput ${ }^{1 \dagger}$, Dong Zeng ${ }^{1 \dagger}$, Abdul Khalique ${ }^{1 \dagger}$, Samia Sharafat Rajput ${ }^{3}$, Hesong Wang ${ }^{2}$, Ying Zhao ${ }^{1}$, \\ Ning Sun ${ }^{1}$ and Xueqin $\mathrm{Ni}^{1^{*}}$
}

\begin{abstract}
Necrotic enteritis (NE) is being considered as one of the most important intestinal diseases in the recent poultry production systems, which causes huge economic losses globally. NE is caused by Clostridium perfringens, a pathogenic bacterium, and normal resident of the intestinal microflora of healthy broiler chickens. Gastrointestinal tract (GIT) of broiler chicken is considered as the most integral part of pathogen's entrance, their production and disease prevention. Interaction between C. perfringens and other pathogens such as Escherichia coli and Salmonella present in the small intestine may contribute to the development of NE in broiler chickens. The antibiotic therapy was used to treat the NE; however European Union has imposed a strict ban due to the negative implications of drug resistance. Moreover, antibiotic growth promoters cause adverse effects on human health as results of withdrawal of antibiotic residues in the chicken meat. After restriction on use of antibiotics, numerous studies have been carried out to investigate the alternatives to antibiotics for controlling NE. Thus, possible alternatives to prevent NE are biotherapeutic agents (Probiotics), prebiotics, organic acids and essential oils which help in nutrients digestion, immunity enhancement and overall broiler performance. Recently, probiotics are extensively used alternatives to antibiotics for improving host health status and making them efficient in production. The aim of review is to describe a replacement to antibiotics by using different microbial strains as probiotics such as bacteria and yeasts etc. having bacteriostatic properties which inhibit growth of pathogens and neutralize the toxins by different modes of action.
\end{abstract}

Keywords: Clostridium perfringens, Necrotic enteritis, Gut health, Probiotics, Antibiotics, Intestinal immunity, Broilers

\section{Introduction}

Necrotic enteritis (NE) is an extensive bacterial disease of broilers which causes significant economic loss by damaging the intestinal mucosa. It has been estimated that NE causes over US\$ 6 billion economic losses every year globally (Moore 2016) and has become fourth leading bacterial induced food-borne disease in the United States (Flynn 2014). The economic loss of NE results in

\footnotetext{
${ }^{*}$ Correspondence: xueqinni@foxmail.com

${ }^{\dagger}$ Danish Sharafat Rajput, Dong Zeng and Abdul Khalique are joint first authors

${ }^{1}$ Animal Microecology Institute, College of Veterinary, Sichuan

Agricultural University, 611130 Chengdu, China

Full list of author information is available at the end of the article
}

impaired growth performance, decreased weight gain and increased feed conversion ratio (FCR). Also, high mortality and greater medication cost make it one of the most costly diseases (Mot et al. 2014; Gaucher et al. 2015). Unfortunately, several predisposing factors such as high fish meal, protozoal infection and stress create promising environment for C. perfringens to proliferation (Rodgers et al. 2015). The gastro intestinal tract (GIT) is considered as the most integral part of productivity, pathogen entrance and disease prevention. The gut health depends upon nutritional and health status of poultry birds including immune system, balanced gut microflora and intestinal mucosa. The gut health affects not only digestion and absorption of nutrients but also
Springer Open (c) The Author(s) 2020. This article is licensed under a Creative Commons Attribution 4.0 International License, which permits use, sharing, adaptation, distribution and reproduction in any medium or format, as long as you give appropriate credit to the original author(s) and the source, provide a link to the Creative Commons licence, and indicate if changes were made. The images or other third party material in this article are included in the article's Creative Commons licence, unless indicated otherwise in a credit line to the material. If material is not included in the article's Creative Commons licence and your intended use is not permitted by statutory regulation or exceeds the permitted use, you will need to obtain permission directly from the copyright holder. To view a copy of this licence, visit http://creativeco mmons.org/licenses/by/4.0/. 
fights against pathogens (Stanley et al. 2012; Bailey 2013). However, disturbance in any physiological process could lead to development of the disease (Dekich 1998) and may affect overall bird growth performance. Therefore, great attention is needed to the health of GIT because it is naturally protected by probiotic bacteria, present in the intestine. When probiotics fail to protect the host against harmful bacteria and viruses, the pathogens start invading tissues by producing lethal toxins and metabolites (Abaidullah et al. 2019). The composition of live microorganisms depend on age and geography; which change under the influence of various factors such as diet variety, the GIT transit time, and intestinal pH (Morgan et al. 2013a, b), leading to emergence of the disease.

Commonly, antibiotic growth promoters (AGPs) were used to treat the NE but use of AGPs have been restricted by European Union (EU) since 2006 (Caly et al. 2015; Lekshmi et al. 2017; Khalique et al. 2019). Moreover, the use of AGP was declared as an alarming threat to public health by WHO in 2012 (Organization 2012) and led to restriction of antimicrobial therapy. After ban on antibiotics, there is an urgent need to search effective alternative strategy to antibiotic growth promoters that could support health and growth performance of broilers. Subsequently, the focus of researchers on substitute strategies have been accelerated to secure livestock animals and poultry birds. Therefore, several amazing non-antibiotic therapies include the administration of competitive exclusion (CE) such as probiotics (Wang et al. 2017; Whelan et al. 2018), prebiotics (Keerqin et al. 2017) and essential oils (Brenes and Roura 2010) have shown bacteriostatic properties (Calik and Ergün 2015). Among nonantibiotic strategies, probiotics have been widely used as an alternative to antibiotics which increase the population of beneficial bacteria and promote intestinal health of the host (M'Sadeq et al. 2015). In addition, probiotic bacteria help in digestion and absorption of the nutrients by producing hydrolytic enzymes. Besides, supplementation of probiotics enhance immunity by modulating intestinal microbiota and reduce pathogenic colonization such as C. perfringens (Hofacre et al. 2019). Therefore, the aim of this review is to summarize the effectiveness of different probiotic strains against C. perfringens in broilers through different modes of action which could be used as alternative to antibiotics.

\section{Clostridium perfringens and toxinotypes}

Clostridium perfringens (C. perfringens) is a gram-positive, rod shaped, spore-forming pathogenic bacterium which is believed to be the main pathogen of NE and subclinical necrotic enteritis (SNE) in poultry associated with chronic damage to the intestinal epithelium (Prescott et al. 2016; Bhogoju et al. 2018; Khalique et al.
2020). To-date, several types of $C$. perfringens have been isolated in different poultry species such as type A, B, C, D, E and G (Keyburn et al. 2010) and each type produces different toxins. In poultry, NE and SNE are mainly caused by type $A$ and $G$ which are normally found in the intestine of healthy poultry birds with less than $10^{2}$ to $10^{4}$ colony-forming units (CFU) per gram of intestinal contents compared to $10^{7}-10^{9} \mathrm{CFU} / \mathrm{g}$ in infected birds (Timbermont et al. 2009; Shojadoost et al. 2012). Several predisposing factors such as coccidiosis, dysbiosis and high fish meal increase the counts of $C$. perfringens. After exposure to predisposing factors, $C$. Perfringens starts secreting harmful substances which play an important role to the development of the disease. The harmful substance like perfrin inhibits the growth of useful bacteria by nutrients competition and creates dysbiosis in the gut (Timbermont et al. 2010). In addition to C. perfrigens, NE is also caused by toxins produced by $C$. perfringens type $A$ and $G$ which produce alpha $(\alpha)$ toxins and netB toxins respectively (Cooper and Songer 2009). For understanding the mechanism of disease, the pathogenesis of NE is shown in (Fig. 1). However, control of C. perfringens is ultimate control of harmful toxins which cause necrosis of intestinal mucosa and results in impaired absorption of nutrients.

Recently discovered toxin produced by $C$. perfringens is NetB toxin. NetB producing strains are capable to infect broiler chickens and lead to NE outbreaks (Wu et al. 2010). The toxinotype G strain produces NetB toxins (Rood et al. 2018) and has been recognized as poreforming toxin (Savva et al. 2013; Yan et al. 2013) coded by plasmid genomes (Keyburn et al. 2008). The isolated strains of $C$. perfringens from healthy broilers do not carry NetB gene (Lacey et al. 2016) while infected birds usually have NetB gene (Keyburn et al. 2010). Thus, NetB gene and other genomic regions are well-known for causing NE in broilers (Parreira et al. 2017). The mechanism of $C$. perfringens virulence strains are still unknown (Lacey et al. 2016; Prescott et al. 2016). However, different $C$. perfringens strains possess different virulence levels. For measuring virulence level, two toxins i.e. NE18 and NE36 isolated from C. perfringens infected broilers which contains NetB gene (Lacey et al. 2018); comparatively NE36 shows greater virulence than NE18 (Keyburn et al. 2013). Additionally, C. perfringens having NetB gene can be the reason of causing NE in the absence of alpha $\alpha$-toxins (Keyburn et al. 2010) (Table 1).

\section{Antibiotic growth promoters and alternatives}

Generally, antibiotic growth promoters were used to improve growth performance and control of $\mathrm{NE}$ in poultry birds. Subsequently, over use of antibiotics developed resistance against pathogens and had 


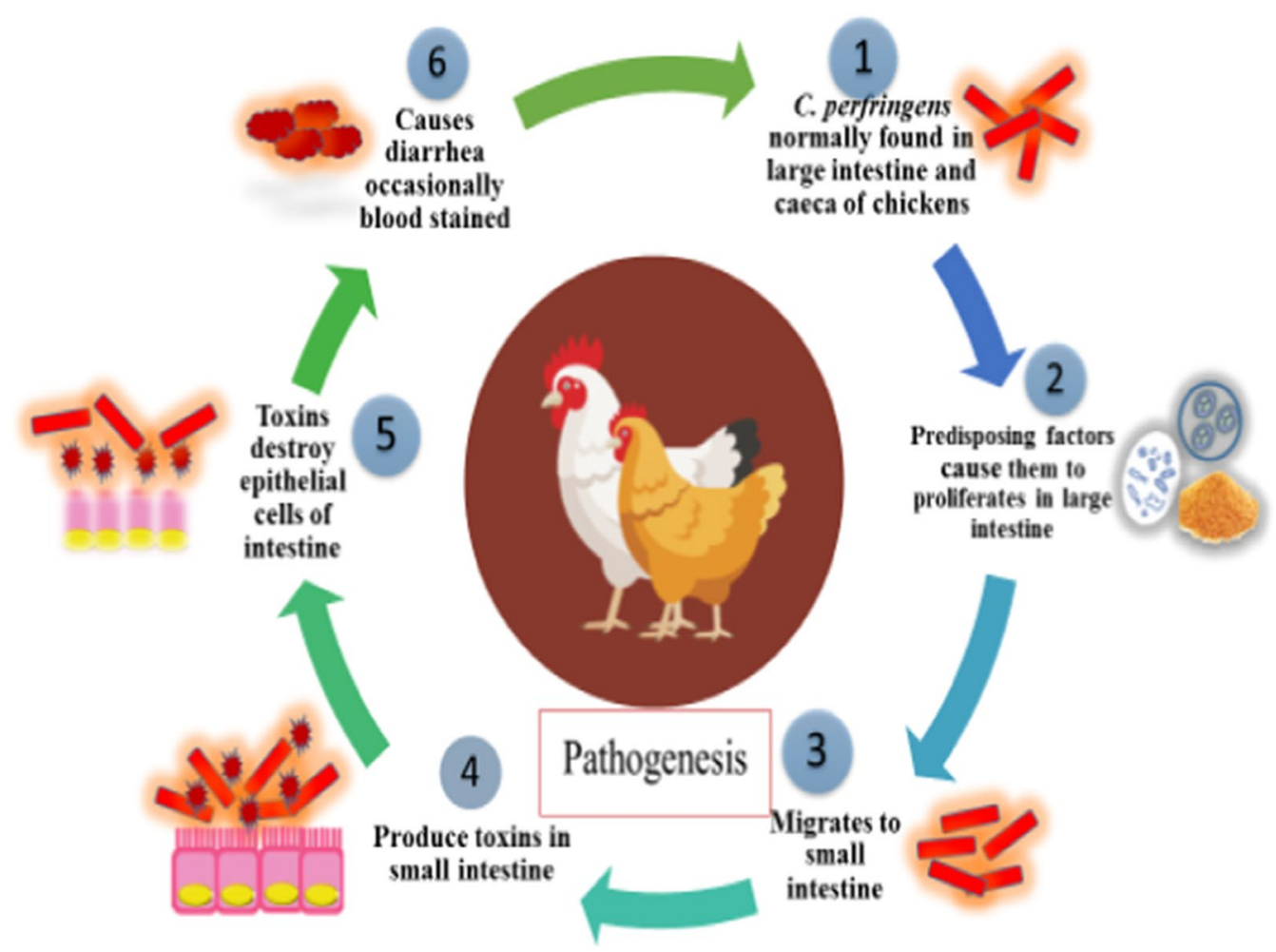

Fig. 1 Pathogenesis of necrotic enteritis in broiler chickens causes destruction of epithelial cells of intestine that leads to blood-stained diarrhea

Table 1 Protozoans/CP and their dose which cause necrotic enteritis in broiler chickens

\begin{tabular}{llll}
\hline Serial no. & Pathogen/protozoans & Infection dose & References \\
\hline 1. & Eimeria necatrix & $2 \times 10^{4}$ oocysts/bird & De Cesare et al. (2020) \\
2. & Eimeria. maxima & $2-5 \times 10^{4}$ oocysts/bird & Gholamiandehkordi \\
& & & et al. (2007), Collier \\
et al. (2008) & Collier et al. (2008) \\
3. & Eimeria. acervulina & $7.5 \times 10^{4}$ oocysts/bird & Shojadoost et al. \\
4. & Clostridium perfringens & $10^{7}-10^{9} \mathrm{CFU} / \mathrm{g}$ of intestinal contents & (2012), Timbermont \\
& & & et al. (2009). \\
\hline
\end{tabular}

hazardous effects on public health in terms of withdrawal of antibiotic residues in broiler meat (Lekshmi et al. 2017). Besides this, multidrug-resistant bacteria were isolated from broilers and were supposed to be the cause of disease in humans that led to restriction of antibiotics by EU (Castanon 2007). The antibiotic therapy destructs the normal micro flora present in GIT (Danzeisen et al. 2011; Goldstein 2011) and allows the proliferation of pathogens which irritates gastric mucosa and cause severe antibiotic-associated diarrhea (Coté and Buchman 2006). Since the ban on use of antibiotics, the incidences of $\mathrm{NE}$ are being increased in broiler chickens (Van Immerseel et al. 2009) and there is an urgent need to search effective alternate strategies to antibiotics. Previously, numerous investigations proved that probiotics, plants (Whelan et al. 2018), enzymes (Engberg et al. 2004), organic acids (Timbermont et al. 2010), and lysozyme (Liu et al. 2010) increase digestion and asbroption of nutrients. Among several alternative strategies, probiotics are the most effective strategy that can be used to control and prevent $\mathrm{NE}$ in broilers. 


\section{Probiotics and production of short chain fatty acids (SCFAs)}

"Probiotics are live microorganisms, when administered in adequate amounts confer a health benefits on the host" (Fao/Who 2001; Hill et al. 2014). Probiotics or direct-fed microbial (DFM) has got great attention due to development of bacterial resistance against antibiotic and subsequently ban on AGPs in animal production (Lekshmi et al. 2017). Different strains of bio-therapeutic agents have different modes of action such as nutrients competition and adhesion with enteric pathogens, as demonstrated in (Fig. 2). Probiotic bacteria aid in digestion and absorption of nutrients by producing hydrolytic enzymes such as amylase, lipase, and protease. Also, these beneficial bacteria enhance immunity by modulating the immune system of the host and altering microbial activities in the intestine (Pourabedin et al. 2015). These live microorganisms have shown defensive characteristics by protecting intestinal mucosa which acts as a barrier as well as function as biological antagonist during clinical trials (Jones et al. 2015), probiotic bacteria perform several functions are shown in (Fig. 3). Besides, probiotics produce antimicrobial substances which inhibit the growth of pathogenic bacteria and neutralize the effects of enterotoxins (Wu et al. 2018). Another action is to stimulate the growth and development of immune organs by peptidoglycan components, present in the bacterial cell wall (Gadde et al. 2017).

SCFAs are produced by useful bacteria which are frequently absorbed and used as an energy substrate by epithelial mucosa of the intestine (Bergman 1990). Briefly, probiotic bacteria modify the gut $\mathrm{pH}$ by producing SCFAs which inhibit the proliferation of pathogens and consequently prevent from intestinal diseases (Jerzsele et al. 2012). In addition, supplementary SCFAs in feed stimulate the immune response (Brisbin et al. 2015; Quinteiro-Filho et al. 2015) and have shown decreased pro-inflammatory cytokine expression in challenged broiler models (Zhang et al. 2011). Butyrate also plays an important role in maintaining intestinal epithelial barrier and growth performance in broiler chickens (Al-Fataftah and Abdelqader 2014; Ritzi et al. 2014). The purpose of this section is to focus on strains

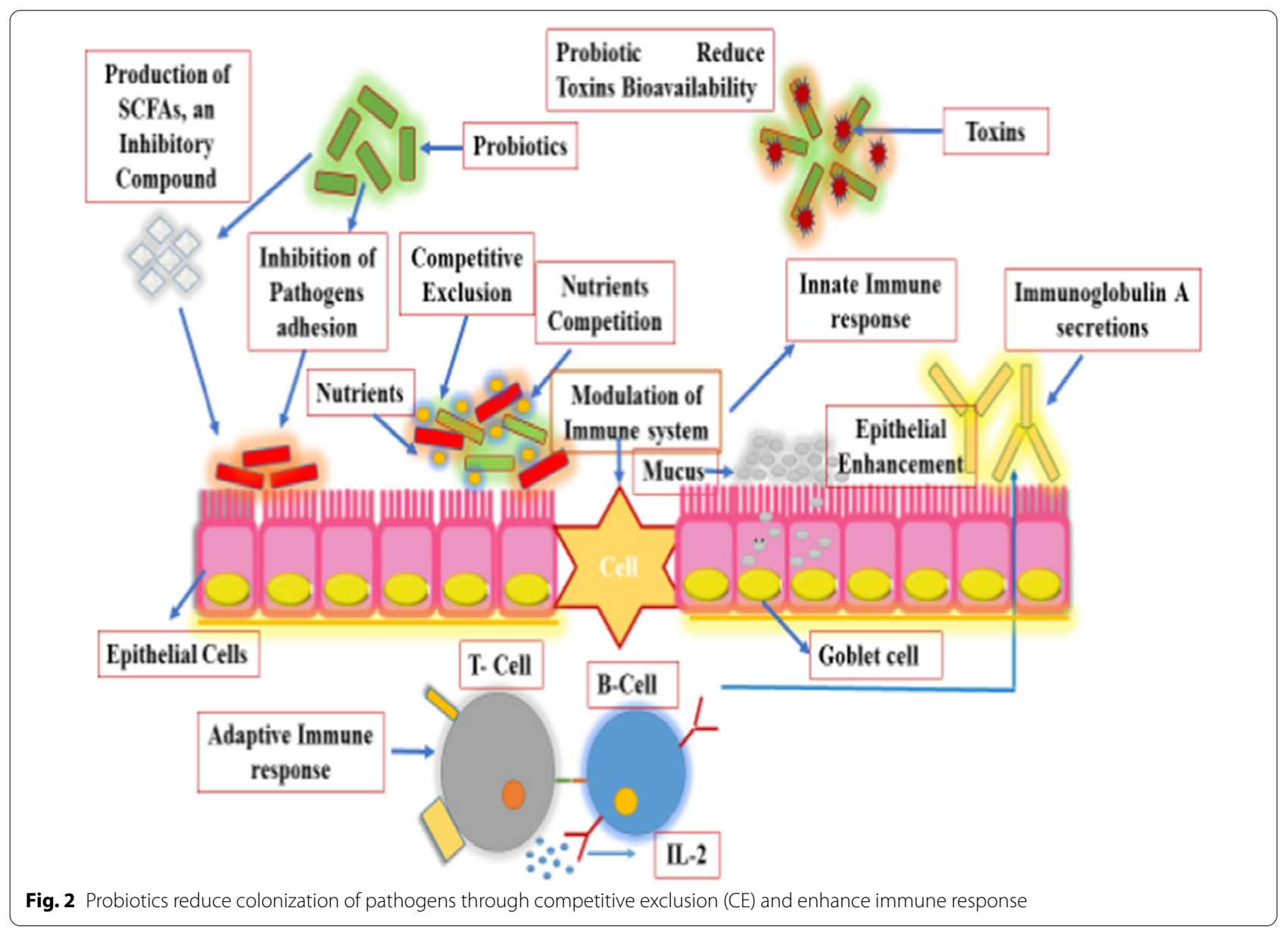




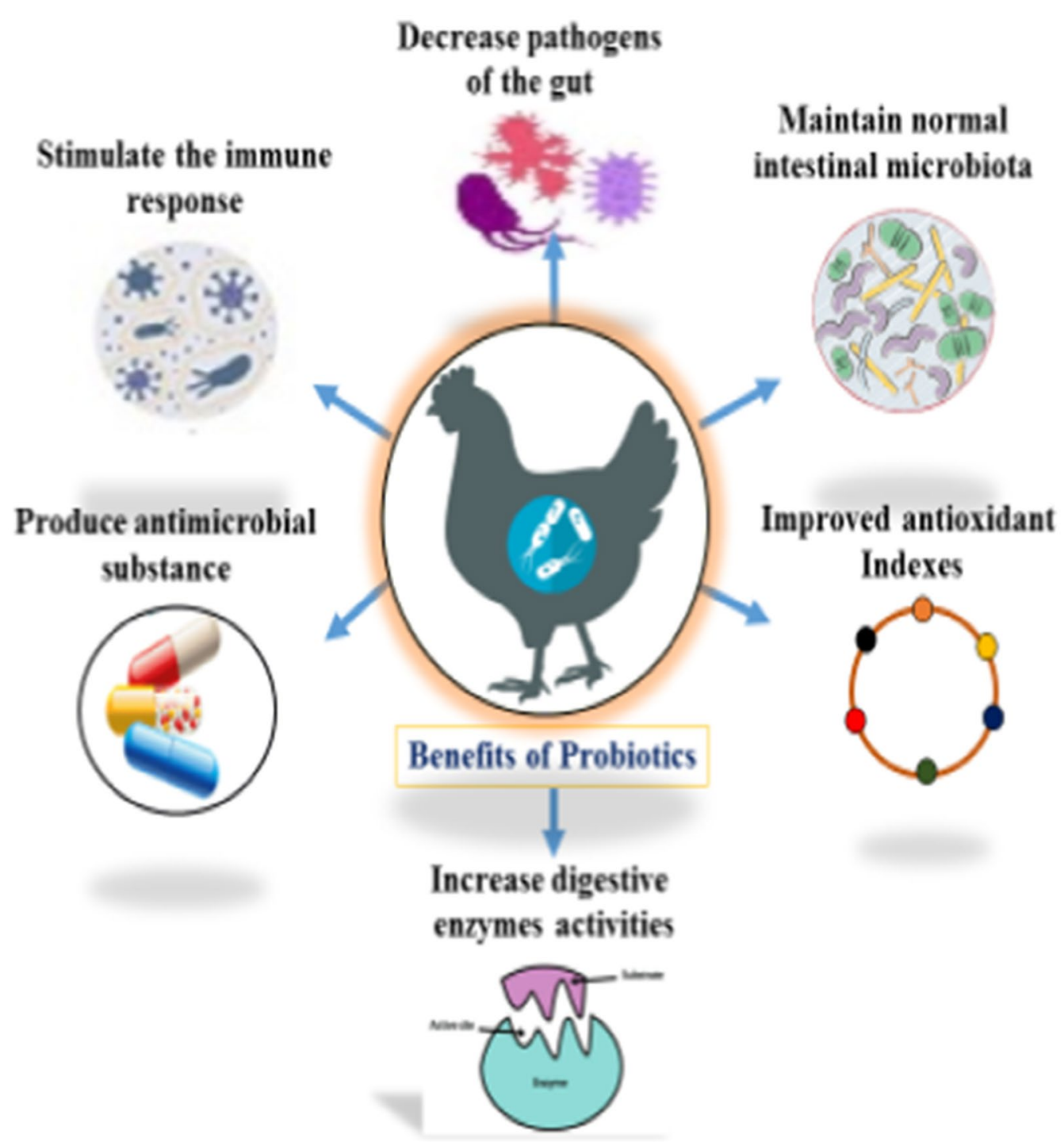

Fig. 3 Probiotics perform many functions in broiler chickens

of probiotic bacteria which are health promoting agents and have antagonistic properties against C. perfringens.

\section{Probiotics improve gut health and prevent NE}

Many strains of probiotic bacteria such as Lactic acid bacteria, Enterococci, Bacilli, and yeast etc. have shown anti $C$. perfringens activities.

\section{Lactic acid bacteria}

Some isloted strains of Lactic acid bacteria (LAB) have probiotic properties which are being used in animals and play extremely vital role in disease prevention (Tavakoli et al. 2017). Several natural species of LAB include Lactobacillus, Streptococcus, Enterococcus,
Carnobacterium, and Lactococcus found in GIT of humans and animals (Vaughan et al. 2005). Useful bacterial strains having probiotic properties are well documented in (Table 2). Isolated strains belonging to Lactobacillus sp. are used as feed supplements to protect the broiler chickens against intestinal pathogens (Higgins et al. 2008). These isolated strains of LAB act as health-promoting agents by maintaining intestinal microbiota of poultry birds (Rajoka et al. 2017). Moreover, they have shown anti-inflammatory (Schreiber et al. 2009) and bacteriostatic properties due to secreting antimicrobial substance such as bacteriocin (Chateau et al. 1993). LAB are producing acids such as lactic acid which lowers the gut $\mathrm{pH}$ and 
Table 2 Dose of different beneficial strains of probiotics which can be used as prophylactic remedy against necrotic enteritis in broiler chickens

\begin{tabular}{llll}
\hline Serial no. & Probiotic & Dietary dose & References \\
\hline 1. & Lactobcillus acidophilus D2/CSL & $1.0 \times 10^{9} \mathrm{CFU} / \mathrm{kg}$ of feed & De Cesare et al. (2020) \\
2. & Lactobacillus plantrum B1 & $2 \times 10^{9} \mathrm{CFU} / \mathrm{kg}$ of feed & Peng et al. (2016) \\
3. & Enterococcus faecium NCIMB 11181 & $5.0 \times 10^{7} \mathrm{CFU} / \mathrm{kg}$ of feed & Wu et al. (2019b) \\
4. & Bacillus licheniformis & $1.0 \times 10^{6} \mathrm{CFU} / \mathrm{g}$ of feed & Liu et al. (2017) \\
5. & Bacillus subtilis & $1.0 \times 10^{8} \mathrm{CFU} / \mathrm{kg}$ of feed & Rajput et al. (2013) \\
6. & Saccharomyces boulardii & $1.0 \times 10^{8} \mathrm{CFU} / \mathrm{kg}$ of feed & Rajput et al. (2013) \\
\hline
\end{tabular}

prevent proliferation of $C$. perfringens found in the intestine (Liu et al. 2014). Additionally, differential abilities of Lactobacillus sp. as probiotic properties $(L$. acidophilus, L. reuteri and L. salivarius) are to modulate the immune response and accelerate the process of phagocytosis by macrophages in broilers (Brisbin et al. 2015). Each probiotic strain has different modes of action for inhibiting growth of pathogens and their toxic metabolites.

Lactobacillus johnsonii (LJ) BS15 is an isolated probiotic strain which can mitigate the inflammation of mitochondria, maintains gastrointestinal homeostasis, and inhibits the non-alcoholic fatty liver disease in obese mice (Xin et al. 2014). The use of L. johnsonii BS15 in-feed enhances growth performance and nutritional value of meat including fatty acids composition particularly the polyunsaturated fatty acid (PUFA) contents (Liu et al. 2017). Additionally, the application of L. johnsonii BS15 in broiler chickens can control lipid deposition and metabolism during SNE infection (Wang et al. 2017) and helps in controlling SNE (Xin et al. 2014). Other probiotic strain of Lactobacillus plantarum and Lactobacillus reuteri improve weight gain by enhancing gut health, increasing intestinal villi height, depth of crypts and decreasing intestinal viscosity (Peng et al. 2016). A solid-state fermented probiotic improves feed efficiency likely through increased energy and protein retention (Shim et al. 2010). An isolated strain of $L$. plantarum increases the proliferation of peripheral lymphocytes and expression of interferon-gamma, interleukin 6 (IL-6) and IL-10 in the intestinal mucosa. While, another probiotic strain named as $L$. reuter increases the levels of serum immunoglobulin A (IgA), IgG, and IgM in healthy chickens (Wu et al. 2019). Conclusively, the inclusion of $L$. plantarum and $L$. reuteri strains result in immediate response to disease causing pathogens such as E. coli, C. perfringens and Brachyspira pilosicoli by increasing the level of serum IgG and decreasing pathogenicity associated with intestinal infection (Ding et al. 2019).

\section{Enterococci}

A strain of Enterococcus faecium (E. faecium) is normally found in GIT of humans and animals. The isolated strains of enterococcus sp. have anti-C. perfringens properties because they generally produce antimicrobial substances, called enterocins and organic acids (Klose et al. 2010) which help in killing pathogens present in the GIT of broilers. European Food Safety Authority (EFSA) has approved E. faecium strain 11181 as a feed supplement for improving growth performance of animals (Pajarillo et al. 2015). Moreover, a study has shown that inclusion of E. faecium increases the villi surface area and architecture of intestine of the host (Samli et al. 2007), help in nutrients absorption and ultimately improve weight gain. These probiotic bacteria also modulate the composition of microflora (Luo et al. 2013) and stimulates the intestinal immune response. In various investigation E. faecium strain has demonstrated the resistance against intestinal pathogens include Salmonella, E. coli, Compylobacter and C. perfringens (Karaffová et al. 2017). Thus, the inclusion of $E$. faecium in-feed can be used to control the NE incidence and health status of broiler chickens.

\section{Bacilli}

Over the last few decades, some strains of Bacillus $s p$. such as $B$. licheniformis and B. subtilis have been uses as probiotics. The genus Bacillus has multiple advantages such as existence in the complex feed manufacturing processes, increased shelf life and robustness under fluctuating conditions within the GIT of broilers (Grant et al. 2018; Mingmongkolchai and Panbangred 2018). In poultry industry, the Bacillus sp. has become highly interesting due to spore-formation, which has ability to survive in harsh environment during pelleted feed processing. They are tolerant to acidic condition (low $\mathrm{pH}$ ) and hydrolytic enzymes present in the GIT of broiler chickens (Elshaghabee et al. 2017). An investigation has shown that Bacillus sp. have anti-inflammatory properties (Eichner et al. 2018) that could prevent inflammation of intestinal mucosa. 
A well known strain of $B$. subtilis as probiotic supplementation prevents proliferation of $C$. perfringens and improves body weight gain (Wu et al. 2018). Oral administration of B. subtilis not only modulates the intestinal health and immunity of broilers (Li et al. 2017), but also improves architecture and height of intestinal villi (Pluske et al. 1996) so that maximum absoption of nutrients could take place. Apart from this, the interaction between secretion produced by probiotic bacteria and pathogens play a key role in boosting immunity and makes intestinal structure healthy (Rajput et al. 2013). $B$. subtillis PB6, a beneficial strain isolated from the gut of healthy chickens produced an antimicrobial substance in vitro with bacteriostatic activity against various strains of Clostridium sp. (Elshaghabee et al. 2017), Escherichia coli, and Campylobacter sp. (Teo and Tan 2006). Most importantly, the B. subtillis PB6 secrets surfactins that have shown anti-microbial (Teo and Tan 2006), anti-viral and anti-tumour properties (Heerklotz and Seelig 2001) which neutralize the effects of pathogens and their toxic metabolites. Conclusively, probiotic PB6 can mitigate the NE in broiler chickens challenged with $C$. perfringens (Jayaraman et al. 2017).

Another isolated strain of B. licheniformis, documented as safe bacteria, is vastly used in the poultry industry with probiotic properties. Inclusion of $B$. licheniformis in-feed can be used to improve growth performance (Xu et al. 2014) as well as substitute to antibiotics for controlling NE in commercial poultry farming (Attia et al. 2012) with no adverse effects. Additionally, B. licheniformis produces several hydrolytic enzymes such as protease, lipase and amylase which increase the digestibility of nutrients and absorption ability in broilers (Rozs et al. 2001). In broiler chickens, the liver is a metabolic centre for lipid metabolism (Theil and Lauridsen 2007) and synthesis of fatty acids (Huang et al. 2013). Though, various stress factors influence the lipid metabolism in the commercial poultry industry (Saneyasu et al. 2013) and NE affected liver undergoes pathological changes (Yang et al. 2010). However, they are capable of reducing antioxidant stress and regulate the level of certain genes expression related to lipid metabolism. Decisively, pretreatment with B. licheniformis has potential to prevent poultry birds challanged with C. perfringens (Zhou et al. 2016).

\section{Saccharomyces yeast}

Some strains of yeasts have shown probiotic properties belonging to the genus saccharomyces, firstly recognized by Henri boulard in 1920s from litchi fruit (Kotowska et al. 2005). Products of yeast are natural growth promoters. Oral administration of $S$. boulardii reinforces the gut ecosystem, modulates the intestinal structure, and increases production of cytokines to strengthen the intestinal mucosa against pathogenic bacteria (Rajput et al. 2013). Additionally, S. boulardii probiotic could improve growth performance and defense against certain pathogens (Rajput and Li 2012) by enhancing immunity of the host. Simultaneously, it enhances activities of trophic factors such as nutrients transportation (Buts et al. 1994), and shows anti-inflammatory properties (Ozkan et al. 2007). Similarly, S. cerevisiae also posses probiotic properties which produces antagonistic effects against pathogens in the lower part of the small intestine that may be due to the production of ethanol (EtienneMesmin et al. 2011). Hence, the use of yeasts strains infeed could inhibit the growth of pathogenic bacteria and improve health status of birds as an ameliorative strategy to antibiotics.

\section{Role of mucosal immunity and probiotics in controlling NE} Intestinal mucosal immunity also known as gut-associated lymphoid tissue (GALT) plays a protective role against pathogens include $C$. perfringens. Generally, pathogens or foreign antigens enter in the body via penetration of mucus membrane include the epithelial lining of respiratory, gastrointestinal and urogenital tracts. However, intestinal epithelium is capable to distinguish the harmful and friendly microorganisms (Dogi et al. 2008). In GIT, beneficial bacteria protect the intestinal mucosa against pathogens where they provide a physical barrier to defend against certain pathogens (Villena et al. 2011). Moreover, the intestinal epithelial surface is covered by mucus; first barrier against admittance of infectious agents while mucosaassociated lymphoid tissue (MALT) such as adenoids and tonsils or enteric Peyer's patches are crucial organs for the protective immune response (Johansson et al. 2011). In addition, probiotics have shown multiple positive effects in stimulating the immune response such as activation of Toll-like receptors (TLRs) that can recognize microorganism's compound in results probiotic stimulates immune activation (Sato et al. 2009) and modulates cytokines production in broilers (Paul et al. 2013). Intestinal crypts secrete the mucus, while the function of Goblet cells is to secrete mucin and moves them between intestinal villi. Furthermore, Paneth cells are also important epithelial cells for secreting anti-microbial peptides (Johansson et al. 2011). Besides mucus and intestinal epithelial cells (IECs) are closely interlinked through tight junctions which were recorded as physical barrier to commensal bacteria as well as pathogens. Beneath this layer of epithelial cells there is lamina propria, containing the GALT that provide an immune response to the enteric mucosa. Increased numbers of lymphoid tissues and immune cells have great importance in protecting gut from the 
pathogens. The GALT consists of lymphoid follicles, including mesenteric lymph nodes and Payer's patches present in small intestine (Delcenserie et al. 2008).

Conclusively, NE is one of the most important devastating intestinal diseases of poultry birds, which causes significant economic losses in terms of reduced production. Many factors negatively affect the GIT of birds and consequently impair nutrients absorption. Additionally, several factors are involved in the development of NE such as high fish meal, dysbiosis, immunosuppression and protozoal infection. However, several pharmaceutical therapies were used to control the NE in broilers but strictly banned by the EU and forced the researchers to discover suitable alternatives to antibiotics. Recent investigations have delineated that use of probiotics in poultry feed stimulates the immunity of the host through antimicrobial substance called bacteriocins which not only inhibit the growth of C. perfringens but also improve gastrointestinal health of the birds. Thus, the use of probiotics in feed supplement also improves weight gain through improving intestinal villi height which helps in absorption of the nutrients. Moreover, the use of these beneficial probiotics can increase the profitability, poultry production and produce good quality meat for consumers. Probiotic bacteria are recognized as one of the most suitable alternative strategies to antibiotics that could reduce the hazardous effects of antibiotics. In future, there is a need to isolate more strains of useful bacteria having probiotic properties that could be used instead of antibiotics for controlling NE in broilers.

\section{Acknowledgements}

Danish Sharafat Rajput wants to thank Lubna Danish for her continuous support, encouragement and cooperation.

\section{Authors' contributions}

DSR, DZ, AK, HW, YZ, NS \& XN finished the writeup, LD and SSR reviewed/ proofread this article and compiled the literature. All authors read and approved the final manuscript.

\section{Funding}

The present study was supported by National Natural Science Foundation of China (31970503) and Sichuan Science and Technology Program (2018HH0103, 2019YFH0060).

\section{Availability of data and materials}

Not applicable.

Ethics approval and consent to participate

Not applicable.

\section{Consent for publication}

Not applicable.

\section{Competing interests}

The authors declare that they have no competing interests.

\section{Author details}

${ }^{1}$ Animal Microecology Institute, College of Veterinary, Sichuan Agricultural University, 611130 Chengdu, China. ${ }^{2}$ Department of Gastroenterology, Nanfang Hospital, Southern Medical University, Guangdong, China. ${ }^{3}$ Department of Veterinary Microbiology, Faculty of Animal Husbandry and Veterinary Sciences, Sindh Agriculture University, 70050 Tandojam, Pakistan.

Received: 26 September 2020 Accepted: 27 November 2020

Published online: 17 December 2020

\section{References}

Abaidullah M, Peng S, Kamran M, Song X, Yin Z (2019) Current Findings on Gut Microbiota Mediated Immune Modulation against Viral Diseases in Chicken. Viruses 11(8):681

Al-Fataftah A-R, Abdelqader A (2014) Effects of dietary Bacillus subtilis on heatstressed broilers performance, intestinal morphology and microflora composition. Anim Feed Sci Technol 198:279-285

Attia YA, Ellakany HF, El-Hamid AA, Bovera F, Ghazaly S (2012) Control of Salmonella enteritidis infection in male layer chickens by acetic acid and/or prebiotics, probiotics and antibiotics. Arch Geflügelk 76:239-245

Bailey R (2013) Gut health in poultry-the world within. Aviagen, Huntsville

Bergman $E$ (1990) Energy contributions of volatile fatty acids from the gastrointestinal tract in various species. Physiol Rev 70(2):567-590

Bhogoju S, Nahashon S, Wang X, Darris C, Kilonzo-Nthenge A (2018) A comparative analysis of microbial profile of Guinea fowl and chicken using metagenomic approach. PLOS ONE 13:3

Brenes A, Roura E (2010) Essential oils in poultry nutrition: Main effects and modes of action. Anim Feed Sci Technol 158(1-2):1-14

Brisbin JT, Davidge L, Roshdieh A, Sharif S (2015) Characterization of the effects of three Lactobacillus species on the function of chicken macrophages. Res Vet Sci 100:39-44

Buts JP, De Keyser N, De Raedemaeker L (1994) Saccharomyces boulardii enhances rat intestinal enzyme expression by endoluminal release of polyamines. Pediatr Res 36(4):522-527

Calik A, Ergün A (2015) Effect of lactulose supplementation on growth performance, intestinal histomorphology, cecal microbial population, and short-chain fatty acid composition of broiler chickens. Poult Sci 94(9):2173-2182

Caly DL, D'Inca R, Auclair E, Drider D (2015) Alternatives to antibiotics to prevent necrotic enteritis in broiler chickens: a microbiologist's perspective. Front Microbiol 6:1336

Castanon J (2007) History of the use of antibiotic as growth promoters in European poultry feeds. Poult Sci 86(11):2466-2471

Chateau N, Castellanos I, Deschamps AM (1993) Distribution of pathogen inhibition in the Lactobacillus isolates of a commercial probiotic consortium. J Appl Bacteriol 74(1):36-40

Collier CT, Hofacre CL, Payne AM, Anderson DB, Kaiser P, Mackie RI, Gaskins HR (2008) Coccidia-induced mucogenesis promotes the onset of necrotic enteritis by supporting Clostridium perfringens growth. Vet Immunol Immunopathol 122(1-2):104-115

Cooper KK, Songer JG (2009) Necrotic enteritis in chickens: a paradigm of enteric infection by Clostridium perfringens type A. "Anaerobe 15(1-2):55-60

Coté GA, Buchman AL (2006) Antibiotic-associated diarrhoea. Exp Opin Drug Saf 5(3):361-372

Danzeisen JL, Kim HB, Isaacson RE, Tu ZJ, Johnson TJ (2011) Modulations of the chicken cecal microbiome and metagenome in response to anticoccidial and growth promoter treatment. PLOS ONE 6:11

De Cesare A, Sala C, Castellani G, Astolfi A, Indio V, Giardini A, Manfreda G, Yildirim A (2020) Effect of Lactobacillus acidophilus D2/CSL (CECT 4529) supplementation in drinking water on chicken crop and caeca microbiome. PLOS ONE 15(1):e0228338

Dekich M (1998) Broiler industry strategies for control of respiratory and enteric diseases. Poult Sci 77(8):1176-1180

Delcenserie V, Martel D, Lamoureux M, Amiot J, Boutin Y, Roy D (2008) Immunomodulatory effects of probiotics in the intestinal tract. Curr Issues Mol Biol 10(1/2):37

Ding S, Wang Y, Yan W, Li A, Jiang H, Fang J (2019) Effects of Lactobacillus plantarum 15-1 and fructooligosaccharides on the response of broilers to pathogenic Escherichia coli O78 challenge. PLoS ONE 14:6

Dogi CA, Galdeano CM, Perdigón G (2008) Gut immune stimulation by non pathogenic Gram (+) and Gram (-) bacteria. Comparison with a probiotic strain. Cytokine 41(3):223-231 
Eichner M, Augustin C, Fromm A, Piontek A, Walther W, Bücker R, Fromm M, Krause G, Schulzke JD, Günzel D, Piontek J (2018) In colon epithelia, Clostridium perfringens enterotoxin causes focal leaks by targeting claudins which are apically accessible due to tight junction derangement. J Infect Dis 217(1):147-157

Elshaghabee FM, Rokana N, Gulhane RD, Sharma C, Panwar H (2017) Bacillus as potential probiotics: status, concerns, and future perspectives. Front Microbiol 8:1490

Engberg RM, Hedemann MS, Steenfeldt S, Jensen BB (2004) Influence of whole wheat and xylanase on broiler performance and microbial composition and activity in the digestive tract. Poult Sci 83(6):925-938

Etienne-Mesmin L, Livrelli V, Privat M, Denis S, Cardot JM, Alric M, BlanquetDiot S (2011) Effect of a new probiotic Saccharomyces cerevisiae strain on survival of Escherichia coli O157: H7 in a dynamic gastrointestinal model. Appl Environ Microbiol 77(3):1127-1131

Fao/Who (2001) Report of a joint FAO/WHO expert consultation on evaluation of health and nutritional properties of probiotics in food including powder milk with live lactic acid bacteria. World Health Organization and Food and Agriculture Organization of the United Nations, London

Flynn D (2014) USDA: US foodborne illnesses cost more than $\$ 15.6$ billion annually. Food Safety News 9

Gadde U, Oh ST, Lee YS, Davis E, Zimmerman N, Rehberger T, Lillehoj HS (2017) The effects of direct-fed microbial supplementation, as an alternative to antibiotics, on growth performance, intestinal immune status, and epithelial barrier gene expression in broiler chickens. Probiotics Antimicrob Proteins 9(4):397-405

Gaucher M-L, Quessy S, Letellier A, Arsenault J, Boulianne M (2015) Impact of a drug-free program on broiler chicken growth performances, gut health, Clostridium perfringens and Campylobacter jejuni occurrences at the farm level. Poult Sci 94(8):1791-1801

Gholamiandehkordi AR, Timbermont L, Lanckriet A, Van Den Broeck W, Pedersen K, Dewulf J, Pasmans F, Haesebrouck F, Ducatelle R, Van Immerseel F (2010) Quantification of gut lesions in a subclinical necrotic enteritis model. Avian Pathol 36(5):375-382

Goldstein EJ (2011) Beyond the target pathogen: ecological effects of the hospital formulary. Curr Opin Infect Dis 24:S21-S31

Grant AQ, Gay CG, Lillehoj HS (2018) Bacillus spp. as direct-fed microbial antibiotic alternatives to enhance growth, immunity, and gut health in poultry". Avian Pathol 47(4):339-351

Heerklotz H, Seelig J (2001) Detergent-like action of the antibiotic peptide surfactin on lipid membranes. Biophys J 81 (3):1547-1554

Higgins SE, Higgins JP, Wolfenden AD, Henderson SN, Torres-Rodriguez A, Tellez G, Hargis B (2008) Evaluation of a Lactobacillus-based probiotic culture for the reduction of Salmonella enteritidis in neonatal broiler chicks. Poult Sci 87(1):27-31

Hill C, Guarner F (2014) The International Scientific Association for Probiotics and Prebiotics consensus statement on the scope and appropriate use of the term probiotic. Nature Reviews Gastroenterology Hepatology 11(8):506-514

Huang J, Zhang Y, Zhou Y, Zhang Z, Xie Z, Zhang J, Wan X (2013) Green tea polyphenols alleviate obesity in broiler chickens through the regulation of lipid-metabolism-related genes and transcription factor expression. J Agric Food Chem 61(36):8565-8572

Jayaraman S, Das PP, Saini PC, Roy B, Chatterjee PN (2017) Use of Bacillus Subtilis PB6 as a potential antibiotic growth promoter replacement in improving performance of broiler birds. Poult Sci 96(8):2614-2622

Jerzsele A, Szeker K, Csizinszky R, Gere E, Jakab C, Mallo JJ, Galfi P (2012) Efficacy of protected sodium butyrate, a protected blend of essential oils, their combination, and Bacillus amyloliquefaciens spore suspension against artificially induced necrotic enteritis in broilers. Poult Sci 91(4):837-843

Johansson ME, Larsson JMH, Hansson GC (2011) The two mucus layers of colon are organized by the MUC2 mucin, whereas the outer layer is a legislator of host-microbial interactions. Proc Natl Acad Sci 108(Supplement 1):4659-4665

Jones RM, Desai C, Darby TM, Luo L, Wolfarth AA, Scharer CD, Ardita CS, Reedy AR, Keebaugh ES, Neish AS (2015) Lactobacilli modulate epithelial cytoprotection through the Nrf2 pathway. Cell reports 12(8):1217-1225

Karaffová V, Marcinková E, Bobíková K, Herich R, Revajová V, Stašová D, Kavul'ová A, Levkutová M, Levkut M, Lauková A, Ševčíková Z (2017) TLR4 and TLR21 expression, MIF, IFN- $\beta$, MD-2, CD14 activation, and slgA production in chickens administered with EFAL41 strain challenged with Campylobacter jejuni. "Folia Microbiologica 62(2):89-97

Keerqin C, Morgan N, Wu SB, Swick RA, Choct M (2017) Dietary inclusion of arabinoxylo-oligosaccharides in response to broilers challenged with subclinical necrotic enteritis. British poultry science 58(4):418-424

Keyburn AL, Boyce JD, Vaz P, Bannam TL, Ford ME, Parker D, Di Rubbo A, Rood $\mathrm{Jl}$, Moore RJ (2008) NetB, a new toxin that is associated with avian necrotic enteritis caused by Clostridium perfringens. PLoS Pathogens 4:2

Keyburn AL, Portela RW, Sproat K, Ford ME, Bannam TL, Yan X, Rood Jl, Moore RJ (2013) Vaccination with recombinant NetB toxin partially protects broiler chickens from necrotic enteritis. Veterinary research 44(1):54

Keyburn AL, Yan XX, Bannam TL, Van Immerseel F, Rood Jl, Moore RJ (2010) Association between avian necrotic enteritis and Clostridium perfringens strains expressing NetB toxin. Vet Res 41(2):1-8

Khalique A, Zeng D, Shoaib M, Wang H, Qing X, Rajput DS, Pan K, Ni X (2020) Probiotics mitigating subclinical necrotic enteritis (SNE) as potential alternatives to antibiotics in poultry. AMB Express 10(1):1-10

Khalique A, Zeng D, Wang H, Qing X, Zhou Y, Xin J, Zeng Y, Pan K, Shu G, Jing B, Shoaib M (2019) Transcriptome analysis revealed ameliorative effect of probiotic Lactobacillus johnsonii BS15 against subclinical necrotic enteritis induced hepatic inflammation in broilers. Microb Pathog 132:201-207

Klose V, Bayer K, Bruckbeck R, Schatzmayr G, Loibner AP (2010) In vitro antagonistic activities of animal intestinal strains against swine-associated pathogens. Vet Microbiol 144(3-4):515-521

Kotowska M, Albrecht P, Szajewska H (2005) Saccharomyces boulardii in the prevention of antibiotic-associated diarrhoea in children: a randomized double-blind placebo-controlled trial. Aliment Pharmacol Ther 21(5):583-590

Lacey JA, Allnutt TR, Vezina B, Van TT, Stent T, Han X, Rood JI, Wade B, Keyburn AL, Seemann T, Chen H (2018) Whole genome analysis reveals the diversity and evolutionary relationships between necrotic enteritiscausing strains of Clostridium perfringens. Bmc Genomics 19(1):379

Lacey JA, Johanesen PA, Lyras D, Moore RJ (2016) Genomic diversity of necrotic enteritis-associated strains of Clostridium perfringens: a review. Avian Pathol 45(3):302-307

Lekshmi M, Ammini P, Kumar S, Varela MF (2017) The food production environment and the development of antimicrobial resistance in human pathogens of animal origin. Microorganisms 5(1):11

Li Z, Wang W, Lv Z, Liu D, Guo Y (2017) Bacillus subtilis and yeast cell wall improve the intestinal health of broilers challenged by Clostridium perfringens. British poultry science 58(6):635-643

Liu D, Guo Y, Wang Z, Yuan J (2010) Exogenous lysozyme influences Clostridium perfringens colonization and intestinal barrier function in broiler chickens. Avian Pathol 39(1):17-24

Liu H, Zhang J, Zhang S, Yang F, Thacker PA, Zhang G, Qiao S, Ma X (2014) Oral administration of Lactobacillus fermentum 15007 favors intestinal development and alters the intestinal microbiota in formula-fed piglets. J Agric Food Chem 62(4):860-866

Liu L, Ni X, Zeng D, Wang H, Jing B, Yin Z, Pan K (2017) Effect of a dietary probiotic, Lactobacillus johnsonii BS15, on growth performance, quality traits, antioxidant ability, and nutritional and flavour substances of chicken meat. Animal Production Science 57(5):920-926

Luo J, Zheng A, Meng K, Chang W, Bai Y, Li K, Cai H, Liu G, Yao B (2013) Proteome changes in the intestinal mucosa of broiler (Gallus gallus) activated by probiotic Enterococcus faecium. Journal of proteomics 91:226-241

M'Sadeq SA, Wu S, Swick RA, Choct M (2015) Towards the control of necrotic enteritis in broiler chickens with in-feed antibiotics phasing-out worldwide. Animal Nutrition 1(1):1-11

Mingmongkolchai S, Panbangred W (2018) Bacillus probiotics: an alternative to antibiotics for livestock production. J Appl Microbiol 124(6):1334-1346

Moore RJ (2016) Necrotic enteritis predisposing factors in broiler chickens. Avian Pathol 45(3):275-281

Morgan XC, Segata N, Huttenhower C (2013) Biodiversity and functional genomics in the human microbiome. Trends Genetics 29(1):51-58

Mot D, Timbermont L, Haesebrouck F, Ducatelle R, Van Immerseel F (2014) Progress and problems in vaccination against necrotic enteritis in broiler chickens. Avian Pathol 43(4):290-300

Organization WH (2012) The evolving threat of antimicrobial resistance: options for action. World Health Organization, Geneva 
Ozkan T, Sahin E, Erdemir G, Budak F (2007) Effect of Saccharomyces boulardii in children with acute gastroenteritis and its relationship to the immune response. Journal of international medical research 35(2):201-212

Pajarillo EA, Chae JP, Balolong MP, Kim HB, Park CS, Kang DK (2015) Effects of probiotic Enterococcus faecium NCIMB 11181 administration on swine fecal microbiota diversity and composition using barcoded pyrosequencing. Anim Feed Sci Technol 201:80-88

Parreira VR, Ojha S, Lepp D, Gohari IM, Zhou H, Susta L, Gong J, Prescott JF (2017) Necrotic enteritis locus 1 diguanylate cyclase and phosphodiesterase (cyclic-di-GMP) gene mutation attenuates virulence in an avian necrotic enteritis isolate of Clostridium perfringens. Veterinary Microbiol 208:69-73

Paul MS, Brisbin JT, Abdul-Careem MF, Sharif S (2013) Immunostimulatory properties of Toll-like receptor ligands in chickens. Vet Immunol Immunopathol 152(3-4):191-199

Peng Q, Zeng XF, Zhu JL, Wang S, Liu XT, Hou CL, Thacker PA, Qiao SY (2016) Effects of dietary Lactobacillus plantarum B1 on growth performance, intestinal microbiota, and short chain fatty acid profiles in broiler chickens. Poultry science 95(4):893-900

Pluske JR, Thompson MJ, Atwood CS, Bird PH, Williams IH, Hartmann PE (1996) Maintenance of villus height and crypt depth, and enhancement of disaccharide digestion and monosaccharide absorption, in piglets fed on cows' whole milk after weaning. Br J Nutr 76(3):409-422

Pourabedin M, Guan L, Zhao X (2015) Xylo-oligosaccharides and virginiamycin differentially modulate gut microbial composition in chickens. Microbiome 3(1):15

Prescott JF, Smyth JA, Shojadoost B, Vince A (2016) Experimental reproduction of necrotic enteritis in chickens: a review. Avian Pathol 45(3):317-322

Quinteiro-Filho W, Brisbin J, Hodgins DC, Sharif S (2015) Lactobacillus and Lactobacillus cell-free culture supernatants modulate chicken macrophage activities. Res Vet Sci 103:170-175

Rajoka MS, Shi J, Zhu J, Shao D, Huang Q, Yang H, Jin M (2017) Capacity of lactic acid bacteria in immunity enhancement and cancer prevention. Appl Microbiol Biotechnol 101(1):35-45

Rajput IR, Li LY, Xin X, Wu BB, Juan ZL, Cui ZW, Yu DY, Li WF (2013) Effect of Saccharomyces boulardii and Bacillus subtilis B10 on intestinal ultrastructure modulation and mucosal immunity development mechanism in broiler chickens. Poult Sci 92(4):956-965

Rajput IR, Li WF (2012) Potential role of probiotics in mechanism of intestinal immunity. Pakistan Vet J 32:3

Ritzi MM, Abdelrahman W, Mohnl M, Dalloul RA (2014) Effects of probiotics and application methods on performance and response of broiler chickens to an Eimeria challenge. Poult Sci 93(11):2772-2778

Rodgers NJ, Swick RA, Geier MS, Moore RJ, Choct M, Wu SB (2015) A multifactorial analysis of the extent to which Eimeria and fishmeal predispose broiler chickens to necrotic enteritis. Avian Dis 59(1):38-45

Rood JI, Adams V, Lacey J, Lyras D, McClane BA, Melville SB, Moore RJ, Popoff MR, Sarker MR, Songer JG, Uzal FA (2018) Expansion of the Clostridium perfringens toxin-based typing scheme. Anaerobe 53:5-10

Rozs M, Manczinger L, Vágvölgyi C, Kevei F (2001) "Secretion of a trypsin-like thiol protease by a new keratinolytic strain of Bacillus licheniformis. FEMS Microbiol Lett 205(2):221-224

Samli HE, Senkoylu N, Koc F, Kanter M, Agma A (2007) Effects of Enterococcus faecium and dried whey on broiler performance, gut histomorphology and intestinal microbiota. Arch Anim Nutr 61 (1):42-49

Saneyasu T, Shiragaki M, Nakanishi K, Kamisoyama H, Honda K (2013) Effects of short term fasting on the expression of genes involved in lipid metabolism in chicks. Comp Biochem Physiol B: Biochem Mol Biol 165(2):114-118

Sato K, Takahashi K, Tohno M, Miura Y, Kamada T, Ikegami S, Kitazawa H (2009) Immunomodulation in gut-associated lymphoid tissue of neonatal chicks by immunobiotic diets. Poult Sci 88(12):2532-2538

Savva CG, da Costa SP, Bokori-Brown M, Naylor CE, Cole AR, Moss DS, Titball RW, Basak AK (2013) Molecular architecture and functional analysis of NetB, a pore-forming toxin from Clostridium perfringens. J Biol Chem 288(5):3512-3522

Schreiber O, Petersson J, Phillipson M, Perry M, Roos S, Holm L (2009) Lactobacillus reuteri prevents colitis by reducing P-selectin-associated leukocyte-and platelet-endothelial cell interactions. Am J Physiol 296(3):G534-G542
Shim YH, Shinde PL, Choi JY, Kim JS, Seo DK, Pak JI (2010) Evaluation of multimicrobial probiotics produced by submerged liquid and solid substrate fermentation methods in broilers. Asian-Austr J Anim Sci 23(4):521-529

Shojadoost B, Vince AR, Prescott JF (2012) The successful experimental induction of necrotic enteritis in chickens by Clostridium perfringens: a critical review. Vet RES 43(1):74

Stanley D, Keyburn AL, Denman SE, Moore RJ (2012) "Changes in the caecal microflora of chickens following Clostridium perfringens challenge to induce necrotic enteritis. "Veterinary microbiology 159(1-2):155-162

Tavakoli M, Hamidi-Esfahani Z, Hejazi MA, Azizi MH, Abbasi S (2017) Characterization of probiotic abilities of Lactobacilli isolated from Iranian Koozeh traditional cheese. Polish Journal of Food Nutrition Sciences 67(1):41-48

Teo A-L, Tan H-M (2006) Effect of Bacillus subtilis PB6 (CloSTAT) on broilers infected with a pathogenic strain of Escherichia coli. J Appl Poultry Res 15(2):229-235

Theil PK, Lauridsen C (2007) Interactions between dietary fatty acids and hepatic gene expression in livers of pigs during the weaning period. Livestock Sci 108(1-3):26-29

Timbermont L, Lanckriet A, Dewulf J, Nollet N, Schwarzer K, Haesebrouck F, Ducatelle R, Van Immerseel F (2010) Control ofClostridium perfringensinduced necrotic enteritis in broilers by target-released butyric acid, fatty acids and essential oils. Avian Pathol 39(2):117-121

Timbermont L, Lanckriet A, Gholamiandehkordi AR, Pasmans F, Martel A, Haesebrouck F, Ducatelle R, Van Immerseel F (2009) Origin of Clostridium perfringens isolates determines the ability to induce necrotic enteritis in broilers. Comp Immunol Microbiol Infect Dis 32(6):503-512

Van Immerseel F, Rood JI, Moore RJ, Titball RW (2009) Rethinking our understanding of the pathogenesis of necrotic enteritis in chickens. Trends Microbiol 17(1):32-36

Vaughan EE, Heilig HG, Ben-Amor K, de Vos WM (2005) Diversity, vitality and activities of intestinal lactic acid bacteria and bifidobacteria assessed by molecular approaches. FEMS Microbiol Rev 29(3):477-490

Villena J, Salva S, Agüero G, Alvarez S (2011) Immunomodulatory and protective effect of probiotic Lactobacillus casei against Candida albicans infection in malnourished mice. Microbiol Immunol 55(6):434-445

Wang H, Ni X, Liu L, Zeng D, Lai J, Qing X, Li G, Pan K, Jing B (2017) Controlling of growth performance, lipid deposits and fatty acid composition of chicken meat through a probiotic, Lactobacillus johnsonii during subclinical Clostridium perfringens infection. Lipids Health Dis 16(1):38

Wang H, Ni X, Qing X, Liu L, Lai J, Khalique A, Li G, Pan K, Jing B, Zeng D (2017) Probiotic enhanced intestinal immunity in broilers against subclinical necrotic enteritis. Front Immunol 8:1592

Whelan RA, Doranalli K, Rinttilä T, Vienola K, Jurgens G, Apajalahti J (2018) The impact of Bacillus subtilis DSM 32315 on the pathology, performance, and intestinal microbiome of broiler chickens in a necrotic enteritis challenge. Poultry Sci 98(9):3450-3463

Wu S-B, Rodgers N, Choct M (2010) Optimized necrotic enteritis model producing clinical and subclinical infection of Clostridium perfringens in broiler chickens. Avian Dis 54(3):1058-1065

Wu Y, Shao Y, Song B, Zhen W, Wang Z, Guo Y, Shahid MS, Nie W (2018) Effects of Bacillus coagulans supplementation on the growth performance and gut health of broiler chickens with Clostridium perfringens-induced necrotic enteritis. J Anim Sci Biotechnol 9(1):9

Wu Y, Wang B, Zeng Z, Liu R, Tang L, Gong L, Li W (2019) Effects of probiotics Lactobacillus plantarum 16 and Paenibacillus polymyxa 10 on intestina barrier function, antioxidative capacity, apoptosis, immune response, and biochemical parameters in broilers. Poult Sci 98(10):5028-5039

Xin J, Zeng D, Wang H, Ni X, Yi D, Pan K, Jing B (2014) Preventing non-alcoholic fatty liver disease through Lactobacillus johnsonii BS15 by attenuating inflammation and mitochondrial injury and improving gut environment in obese mice. Appl Microbiol Biotechnol 98(15):6817-6829

Liu X, Yan H, Le Lv QX, Yin C, Zhang K, Wang P, Hu J (2014) Growth performance and meat quality of broiler chickens supplemented with Rhodopseudomonas palustris in drinking water. British poultry science 55(3):360-366

Yan X-X, Porter CJ, Hardy SP, Steer D, Smith Al, Quinsey NS, Hughes V, Cheung JK, Keyburn AL, Kaldhusdal M, Moore RJ (2013) Structural and functional analysis of the pore-forming toxin,\&nbsp;NetB from Clostridium perfringens. MBio 4(1):e00019-e00013 
ang X, Zhuang J, Rao K, Li X, Zhao R (2010) Effect of early feed restriction on hepatic lipid metabolism and expression of lipogenic genes in broiler chickens. Res Vet Sci 89(3):438-444

Zhang WH, Jiang Y, Zhu QF, Gao F, Dai SF, Chen J, Zhou GH (2011) Sodium butyrate maintains growth performance by regulating the immune response in broiler chickens. British poultry science 52(3):292-301

Zhou M, Zeng D, Ni X, Tu T, Yin Z, Pan K, Jing B (2016) Effects of Bacillus licheniformis on the growth performance and expression of lipid metabolism-related genes in broiler chickens challenged with Clostridium perfringens-induced necrotic enteritis. Lipids Health Dis 15(1):48

\section{Publisher's Note}

Springer Nature remains neutral with regard to jurisdictional claims in published maps and institutional affiliations.

\section{Submit your manuscript to a SpringerOpen ${ }^{\circ}$ journal and benefit from:}

- Convenient online submission

- Rigorous peer review

- Open access: articles freely available online

- High visibility within the field

- Retaining the copyright to your article

Submit your next manuscript at $\boldsymbol{\nabla}$ springeropen.com 